\title{
GLAMPING AS A PROMISING NICHE IN TOURISM AND HOTEL BUSINESS
}

Boiko V. O.

\section{INTRODUCTION}

Modern tourism and hotel industries are popular dynamic areas, considerably affecting economic development of every country, suffered a significant financial loss during the crisis of COVID-19. The Ukrainian hotel market saw the first half of 2020 off without a big regret. A lack of business tourists, a 50\% reduction in hotel occupancy rates in almost all the segments, a decline in average check have become main problems for hoteliers. In spite of certain conservatism in hotel and tourism business, everyone had to adapt quickly to changeable circumstances and observe leading tendencies, generate new ideas and reformat their business.

To cope with the crisis, hoteliers had to adapt their product to a new reality. For instance, global hotel chains, such as Radisson and Accor, practice combination of hotels with office centers and co-workings. Ribas Hotels Group has suggested such an option for the Ukrainian market as well. There are tens of kinds of lodging for those who search for rural luxury and immaculate nature, ranging from tents and tipis for glamping to cabins, nomad's tents ra houses in trees.

\section{Glamping as a new type of environmentally-friendly business in Ukraine's economy}

The word "glamping" originated in English and means a glamorous camping, realized as light comfortable houses or tents. It is a relatively new format of leisure oriented towards those who want to be nearer to nature and enjoy hotel comfort. The first glampers, without exaggeration, were medieval kings, who arranged large tents in military campaigns. Definitely, such tents had everything necessary for the comfort of a king and his escort. The format of tent leisure with comfort enjoyed the greatest popularity in the $19^{\text {th }}$ century among rich lovers of hunting who set off for the expeditions to Africa and South America. In their temporary accommodations there were not only comfortable beds, but also true libraries and cast iron baths. Glamping in a modern form became popular in the middle of the 2000s in Great Britain where organizers of summer festivals began arranging comfortable camps for fastidious visitors. This movement started developing and currently there are 
many places in the world where one can stay in original glamps. This type of leisure is just coming to Ukraine ${ }^{1}$.

The global glamping is developing quite actively. Nowadays the largest markets are the USA, Great Britain and Australia, the total volume of the market being $\$ 3$ billion. There are over 5 million people who have already enjoyed leisure in glamps. There are people who cannot even imagine any other type of tourism. It is forecasted that the global glamping market will have reached the volume of $\$ 4.3$ billion by $2025^{2}$.

The modern trends of social development are an increase in the interaction with the environment, a rise in the clothes made of natural textiles, organic food etc. Due to awareness and ecological responsibility, most people direct their activities towards "natural" area to organize running environmentallyfriendly business. Currently the development of tourism business, eco-hotel and glamping enterprises in particular, is a promising trend for Ukraine's economy ${ }^{3}$.

Glamping implies outdoor leisure, even in nature reserves, but with all the necessary conditions for lodging. Unlike hotels, glampings can be installed anywhere and moved from one place to another, even to the places where any other construction is prohibited that is obviously impossible with hotels. The advantages of a glamping are as follows: firstly, it is repaid much more quickly than hotels - for 2-3 years. Secondly, the installation of a glamping does not require any allowance documentations. In terms of legislation, a glamp is classified as a usual tent, therefore it can be placed almost anywhere, however, it is necessary to agree it with a forestry if this glamping is in a forest or a nature reserve, or with an enterprise owning it. In some cases, certain payments can be charged for the installation of a glamp. In addition, the installation of a glamping does not damage the environment. A glamp is a construction made of metal, wood and tent fabrics $\mathrm{PVC}^{4}$.

${ }^{1}$ Shcho take hlempinh ta de yoho shukaty v Ukraini [What is glamping and where it can be found in Ukraine]. URL: https://veterdoit.com/shcho-take-hlempinh-ta-de-yohoshukaty-v-ukraini/ (Accessed 20 March 2021).

${ }^{2}$ Namet $\mathrm{z}$ kondytsionerom ta Wi-Fi: shcho take hlempinh ta chy ye vin $\mathrm{v}$ Ukraini [A tent with an air-conditioner and Wi-Wi: what is glamping and if it is available in Ukraine]. URL: https://shotam.info/namet-z-kondytsionerom-ta-wi-fi-shcho-takehempinh-ta-chy-ie-vin-v-ukraini/

${ }^{3}$ Hranovska, V. H. \& Boiko, V. O. (2020), Funktsionuvannia ekohoteliv v Ukraini yak chynnyk aktyvizatsii pidpryiemnytskoi diialnosti [Functioning of eco-hotels in Ukraine as a factor of activization of entrepreneurial activity]. Ekonomika APK, 3, pp. 57-65. [In Ukrainian] DOI: https://doi.org/10.32317/2221-1055.202003057

${ }^{4}$ Glemping: v Ukraine poyavilsia novyy biznes generiruyushchiy pribyl' [Glamping: a new business has appeared in Ukraine that generates profits]. URL: http://derevo.ua/ articles/details/glemping-v-ukraine-poyavilsya-novyj-biznes-generir-99. 
Over the past few years "glamping" has become one of those popular brands of tourism industry which enjoys great popularity among tourists. The combination of the words "glamour" and "camping" has contributed to an increase in this tendency, since the growth of mass tourism has made more people keep ecological atmosphere of responsible journeys. According to Oxford Dictionary, glamping is "a form of camping involving accommodation and facilities more luxurious than those associated with traditional camping ". This word was used for the first time in the United Kingdom in 2005, and was added to the Dictionary in 2016.

There are about a thousand working glampings in the world. Currently the largest markets are the USA, Great Britain and Australia, and the total volume in the global market is $\$ 3$ bilion. According to the data of the British Tourism Bureau "Campingselection", the market of glampings grows by $21 \%$ annually, and according to the forecasts its volume will have reached about $\$ 4$ billion by 2021. A glamping is much more than a nice tent, all over the world there are a variety of incredible trends ranging from popular eco-glampings, trailer glampings to Antarctic luxury-tents on a glacier ${ }^{5}$.

The southern part of our country is one of the places having substantial resources and labor potential to develop all types of tourism. The issues of developing hotel and tourism business in Kheron region, in our opinion, are very important, eventually, they are oriented towards external and internal social and economic development. Kherson region is a unique territory for tourism, leisure and recreation, since it has many benefits for the formation and development of a powerful resort and tourism complex. The region has a wide access to the Dnipro water main, ant it is the only region in Ukraine with the access to two seas - the Black sea and the Azov sea. The only natural dessert in Europe - Oleshky sands - is the largest artificial forest in the world and even the unique mountain landscapes in the middle of the Steppes - the Stanislav mountains are located in Kherson region ${ }^{6,7}$.

The Covid-19 pandemic has made considerable changes to the plans for holidays of many people not only in terms of external, but also internal

\footnotetext{
${ }^{5}$ Namet $\mathrm{z}$ kondytsionerom ta Wi-Fi: shcho take hlempinh ta chy ye vin $\mathrm{v}$ Ukraini [A tent with an air-conditioner and Wi-Wi: what is glamping and if it is available in Ukraine]. URL: https://shotam.info/namet-z-kondytsionerom-ta-wi-fi-shcho-takehempinh-ta-chy-ie-vin-v-ukraini/ (Accessed 20 March 2021).

${ }^{6}$ Boiko, V.O. (2020), The development of green tourism in the southern region. Entrepreneurship in the agrarian sector: global challenges and effective management: Proceedings of the $1^{\text {st }}$ International scientific practical conference in 2 parts, (pp. 65-68). 12-13 liutoho 2020, Zaporizhzhia, Ukraine : ZNU.

${ }^{7}$ Boiko, V. O. (2020), Green tourism as a perspective direction for rural entrepreneurship development. Scientific approaches to modernizing the economic system: vector of development : collective monograph. Lviv-Torun : Liha-Pres, 2020. pp. 1-18.
} 
tourism. The citizens of Ukraine, for whom the prices for leisure at the sea and the Carpathian mountain resorts are too high, travel around picturesque places, familiar to them, by their own or rental cars, having their tents for leisure and home food instead of hotel rooms, restaurants and cafes $8,9,10,11,12$. Comfortable glampings not inferior to hotels by their facilities can be an alternative to traditional forms of recreation and lodgings for the night. But unlike hotels, glampings have considerable advantages, because they can be installed anywhere, moved from one place to another without filling in any bureaucratic papers, just having allowances from local authorities. Glampings can be installed in the places, where any other construction is prohibited, that is impossible for hotels and resorts.

The Ministry of environmental protection and natural resources of Ukraine together with the Association of local authorities "The Carpathian Euro-region - Ukraine" and the national nature parks prepared the project "Glampings - creation of an exclusive tourism product in nature reserves". The specificity of the project is the development of tourism in the territories of the nature reserve funds that will not have a negative impact on natural ecosystems. And glampings, as it was mentioned by the Ministry, will become that combination of traditional campings with comfortable conditions of hotels for tourists.

According to the project, comfortable camps are planned to be created in the Regional Landscape Park "Kramatorskyi" (Donetsk region), the National Nature Park "Synevyr" (Zakarpattia region), the National Nature Park "Skolivski Beskydy" (Lviv region) and the Regional Landscape Park "Dnistrovskyi" (Ivano-Frankivsk region). This project stipulates that efficiency of using tourism potential of nature reserves should be increased and an exclusive product for tourism - arranging glamping-locations -

${ }^{8}$ Boiko V.O., and Drahota I.P. Glamping is an exclusive tourism product of the present. The $1^{\text {st }}$ International Science Conference on Multidisciplinary Research, January 19-21, 2021, Berlin, Germany, pp. 208-210.

${ }^{9}$ Romanenko, Y. O., Boiko, V. O., Shevchuk, S. M., Barabanova, V. V., \& Karpinska, N. V.(2020). Rural development by stimulating agro-tourism activities. International Journal of Management, № 11(4), C. 605-613. doi:10.34218/IJM.11.4.2020.058.

${ }^{10}$ Kyrylov, Y., Hranovska, V., Boiko, V., Kwilinski, A., \& Boiko, L. (2020). International Tourism Development in the Context of Increasing Globalization Risks: On the Example of Ukraine's Integration into the Global Tourism Industry. Journal of Risk and Financial Management, 13(12), 303. DOI: https://doi.org/10.3390/jrfm13120303

${ }^{11}$ Boiko, V. (2020), "Rural green tourism in Ukraine: problems and prospects", Agrosvit, vol. 22, pp. 58-65. DOI: 10.32702/2306-6792.2020.22.58.

12 Boiko V.O., Kliuchnyk A.V., and Pivnova L.V. (2020), "Increasing competitiveness of enterprises of ecological (green) tourism". Bulletin of Kherson National Technical University, vol. 3, pp. 213-222. DOI: https://doi.org/10.35546/kntu2078-4481.2020.3.28 
in picturesque places of Ukraine should be created, that will be an incentive for a considerable increase in its competitiveness among leading tourism countries.

Nowadays there is a global tendency for conserving natural resources, since they are limited and non-renewable. Therefore, the development of ecohotel industry in the form of glampings, whose main activity is aimed at conserving natural resources, is highly profitable business, capable of making a considerable contribution to the growth of the gross domestic product with relatively low costs and a short period of repayment.

In comparison with other types of tourism, eco-tourism has a more distinct social and economic direction. It can play an important role in the economy of any region and provide nature territories and local people engaged in this area with new economic prospects.

Recently ecological tourism has started occupying an important position in the global tourism industry. According to the evaluation of the experts of the World Tourism Organization (WTO), ecological tourism is going to develop at such high rates. In the first place, it will have a positive impact on economic development of the countries which still have valuable natural resources at their disposal. According to the definition of scientists, ecological tourism involves unforgettable journeys whose main aim is to study and conserve cultural environment, the main mission of which is to protect and preserve valuable nature landscapes showing their beauty to tourists. This is its essential difference from other types of tourism, which involuntarily damage the environment. In order to eliminate negative consequences of the functioning of the global tourism industry, it is necessary to use nature and cultural-historical monuments more efficiently and carefully in order to make them available for future generations.

Eco-tourism as one of the types of tourism originated in the 70's of the past century in the USA and developed countries of Europe. The main reason for the emergence of ecological tourism at the current stage is loads on natural and cultural-historical resources, increasing inversely to the number of tourist arrivals. The contradiction between meeting tourism demands and using natural resources efficiently becomes obvious.

The main components of eco-tourism are:

- "learning nature", i.e. journeys imply the elements of examining nature, acquiring new knowledge and skills by tourists;

- "conserving ecosystems" involves appropriate behavior of a group in the route and participation of tourists and tour operators in the programs and events aimed at protecting the environment;

- "respecting interests of local population" means compliance with local rules and customs and also a contribution of tourism to social and economic development of tourism centers. 
The main tasks of the development of ecological tourism in Ukraine are:

- legislative and regulatory execution of eco-tourism activities;

- implementation of en economic mechanism of charging a tourism service fee, creating self-sustained recreation structures in Ukraine on the basis of self-sufficiency, self-financing and self-repayment;

- financial and organizational support for recreation-tourism infrastructure in compliance with international standards (conditions of tourist lodging, transport etc);

- formation of an intellectual-humanistic worldview and a patriotic attitude towards natural and cultural heritage of the country in holidaymakers;

- creation and arrangement of scientific-informative tourism routes and ecological-educational excursion paths according to the parameters of internal and external landscape diversity of natural terrains;

- substantiation of the mechanism of determining acceptable volumes of recreation loads on landscape complexes of nature reserves used for leisure, tourism and treatment;

- inventory, quantitative and qualitative evaluation of natural recreational (balneology, climate, forests, landscapes) and historical-cultural (museums, architectural monuments, fortifications) resources available in nature reserves ${ }^{13}$.

Ecological tourism in Ukraine has started developing recently, but nowadays many participants of the tourism market are offering their products with the prefix "eco". However, it is necessary to acknowledge that not everyone is aware of the classical understanding of the term "eco-tourism", implying not only outdoor leisure, but also an educational component, consciousness of tourists and the key role of local cultures ${ }^{14}$.

A positive effect of the factors on the formation and development of ecotourism allows the country to achieve high economic results: steady development of economic activity and successful solutions to social problems. However, the process is slowed down by complicated logistics - the road quality in Ukraine is known to leave much to be desired. The situation is getting more complicated because officials, tourism agencies and other representatives of the industry consider the concept of eco-tourism not accurately regarding any outdoor leisure as ecological tourism.

${ }^{13}$ Petruk V.H. et al. Ekoheohrafiia ta ekoturyzm: pidruchnyk [Eco-geography and ecotourism : textbook / V.H. Petruk, O.V. Bondarchuk, I.A. Trach, O.Yu. Panasiuk, Yu.I. Tsaruk, V.D. Vakoliuk. Vinnytsia : LLC "Nilan-LTD», 2016. 178 p.

${ }^{14}$ Ekoturyzm u sviti [Eco-tourism in the world]. URL: https://we.org.ua/rizne/ ekoturyzm-u-sviti/ 
Following the example of the European tourism practice, new forms of eco-tourism are emerging in the country: nature parks, eco-resorts, ecocottages, eco-paths, glampings etc.

- The standard model of an eco-complex has well-trained personnel and professional guides who communicate with its guests. Eco-complexes are located in immaculate nature territories. They are of great ecological importance and have powerful programs for the environmental protection. They support ethical practices of employment and contribute to the development of local economies. The best technologies are used to save energy and handle wastes efficiently.

- Eco-resorts are similar to the standard model in visual characteristics and construction solutions, however, they differ by purposes, usually located near water bodies and oriented towards offering entertainment services and other personal services (natural health-improving spa-centers, yoga practices etc.).

- Eco-cottages and camps are small houses, located in nature territories, with picturesque sceneries, usually built relatively long ago and for certain purposes, not related to tourism. Many of them are adapted and kept for lodging. Over the past several years "glamping" has become that popular brand of tourism industry that enjoyed great popularity among travelers. The combination of the words "glamour" and "camping" has led to an increase in this tendency since a boom in mass tourism has made more people feel ecological spirit of responsible journeys.

- Rural eco-complexes are simple private dwellings, located in rural territories or in small villages near nature reserves. Maintenance staff and guides are local people without professional skills. They offer opportunities to see exotic wildlife, not isolated from civilization.

- Eco-farms are rural projects using farm houses and other farm constructions. Some of them are adjusted or constructed for a particular purpose. These projects are aimed at earning additional income for farmers and small communities.

The global strategies of social-economic and ecological development determine a significant role of tourism industry as one of the most important areas of life activities. Green tourism is getting more popular and widespread among people during the period of the world economic crisis caused by the Covid-19 pandemic. After Ukraine's adoption of the principles of selfgovernment and self-sufficiency, as a result of the processes of decentralization, green tourism will become a stimulating factor of an increase in the efficiency of economic development of rural areas.

The development of green tourism leads to social welfare, it is considered to be a priority sector in diversification of the agrarian sector of economy and support for the well-being of rural dwellers, but it requires special measures 
during long-time restrictions for movement of internal and external tourism flows. Under conditions of the quarantine, the so-called micro-locations are about to become the main tourism trend, the essence of which consists in short holidays nearer to home and far from popular tourism routes, that will allow saving money and reducing the impact of travelling on the environment.

The development of green tourism is a proven world practice as a way of raising the incomes of rural people. There is currently no systemic national policy in this area in Ukraine. It is necessary to make extensive use of the European practice and to create the necessary legislative environment as soon as possible to overcome the problems hampering the development of rural green tourism based on personal husbandries and farm enterprises.

\section{Types of glampings as an exclusive tourism product}

The current rhythm of life causes permanent stress to a human organism and almost does not leave time for leisure, therefore the state of health and working capacity in the following year depend on a short period of holiday. Healthy food and daily routine, availability of fresh air, and, majorly, its length are important factors in planning holidays. Such conditions are extremely important under conditions of the COVID-19 pandemic, therefore most people prefer short-time tourism ( $1 \ldots 5$ days). It proves that consumers of hotel services will have higher requirements to the conditions for their leisure and it will be necessary for glamping owners to search for additional benefits of such lodgings. The duration of leisure time mainly depends on a person's mental state, long-time leisure will not be good for workaholics and they will start counting days to coming back to work, and also on travelling companions - they should be compatible for a successful holiday ${ }^{15}$.

Most travelers suffer from stress caused by the COVID-19 and regulations require maintaining social distancing. In the new world leisure in the style of glamping is a fantastic variant which can be offered to tourists and which should be necessarily considered by hoteliers. Isolated leisure outdoors is perfectly suitable for travelling during the COVID-19 pandemic. Glamps can accommodate a small number of people and therefore their business model is based of exclusiveness. A traveler has full comfort in the place of natural beauty without overcrowding and social stress.

The global market of glamping is developing actively. The most interesting part of this business is the idea of houses, i.e. glamps. Stationary

${ }^{15}$ Oliinyk O.V., Mostetska T.L., Tarasiuk H.M., Chahaida A.O. Perspektyvy rozvytku hoteliv u styli hlempinh v Ukraini [Prospects for the development of hotels in the style of glamping in Ukraine]. Ekonomika, upravlinnia ta administruvannia [Economics, management and administration ], № 4(90), 2019. P. 38-46. 
glamps can be of different sizes and forms. When determining the location, it is important to consider the target audience of potential clients. The location of glampings can be oriented towards:

- seaside leisure near or far from resorts and settlements;

- family leisure at weekends in the countryside;

- tourism flows, including those on holiday routes;

- road leisure, as a more comfortable type of motels;

- places for fishing and hunting;

- arranging corporate and family parties;

- thematic glamping-camps: sports, musical, in the places of regular historical reconstructions and holidays.

There is a variety of types (forms) of glampings. Here are some of them:

- The Glamp "Stodola" (the village Dolynivka, Lviv region). This space was arranged in the village to hold different events, mainly for weddings and birthday parties. There is a huge white tent in the territory. One can have a holiday in the style of glamping there, and it is very aesthetical and civilized. This wigwam is made of waterproof eco-friendly cotton. Therefore Carpathian rains will not hamper cozy leisure. In the territory, not far from the tent, there is a shower with hot water, toilet, kitchen and grill. The tent is designed for two adults and a child younger than 6 years old. In the territory there is also a house where three persons more can be accommodated.

- The glamping "Shatro" (the village Ulianyky, Kyiv region). A true glamping is situated only 80 kilometers from Kyiv. Its guests can expect leisure outdoors without noise, in the place very similar to the Carpathians. In each tent, designed for 2-4 persons, there is everything for cozy leisure: comfortable beds and furniture, a shower, toilet, air-conditioner, mini-kitchen, terrace and a barbecue zone. In "Shatro" one can also order meals or cook food on their own in the mini-kitchen - all the necessary equipment is available in each glamp. One can also buy products of local producers: wines from the family winery of Hryhorii Kulinichenko from Kaharlyk and cheese from Bukrynsk creamery.

- The glamping "Mandra" (Zatoka, Odesa region). The glamping "Mandra" is located in Zatoka, on the shore of the estuary. There are three glamps for lodging: one glamp on the water for two persons, a VIP glamp for two persons with a kitchen and terrace and a Basic glamp - for three persons with a terrace. Each glamp has a toilet and everything necessary for comfortable leisure. In the territory there is a sports ground for volleyball, a place for campfire, braziers, kayaks and a common leisure zone. It is available all year round.

- The glamping in the hotel "ShyshkiNN" (the village Snovianka, Chernihiv region). Two-story glamps with all conveniences will attract adults and children. In addition to romantics of passing the night in a tent in the pine 
forest, one can be offered services of a hotel level here. The rooms have two double beds, a bathroom, conditioner, mini-kitchen and hair-dries. In the territory of the hotel there is a restaurant, parking lots for cars, playgrounds, and also a SPA-center and an outdoor swimming pool. One can also hire a bicycle, go fishing or shoot a bow. And there is a path to the scenic shores of the river Snov.

- Serfclub\&bechotel (Berdiansk, Zaporizhzhia region). The dome hotel of a glamping type offers comfortable leisure with the seascape and the sunset views. The glamps have everything for minimum comfort: an air-conditioner, fridge, TV-set, micro-wave stove and a kettle. There are also bathrooms in the rooms. In winter comfort is provided by heaters and warm floors.

- Gm Eco Bubble (Yablunytsia, Ivano-Frankivsk region). The glamping offers comfortable lodging in semi-transparent spheres. All the glamps have double beds, a conditioner, electric stove, mini-bar, stove and access to Internet. The glamping has a favorable position near the resort Bukovel.

- The eco-glamping in the Carpathians (the village Kryvopillia, IvanoFrankivsk region). One can pass the night in the glamp paying a reasonable price in the village Kryvopillia in the Carpathians. One can rent domes in Dzvin Space. There is an option for 2-4 persons, with single, double and twotier beds. The conveniences are minimum in the tent: the toilet and shower are located outdoors.

- The eco-glamping "Sfera 365" (Bila Tserkva). Its visitors can be offered to pass the night in a transparent spherical house showing the panorama of the starry night and the lake. Guests are served continental breakfast and offered a free bicycle hire. In the territory there is a sauna, barbecue zone and a terrace. In summer an outdoor swimming pool is available ${ }^{16}$.

Glamping is a good idea for creative entrepreneurs, this business has benefits because it can be created as a pleasure for the soul, developed gradually allowing the realization of brave ideas. And though foreign tourists are a good way to develop business to the international level, it is necessary to start orienting towards internal tourism. It is also important to remember the specificity of the climate and use the nature potential, peculiarity and uniqueness of the territory, where glamps are planned to be located, to the fullest extent.

${ }^{16}$ Shcho take hlempinh ta de yoho shukaty v Ukraini [What is glamping and where it can be found in Ukraine]. URL: https://veterdoit.com/shcho-take-hlempinh-ta-de-yohoshukaty-v-ukraini/ (Accessed 20 March 2021). 


\section{What is necessary to know to start your own glamp-business}

Modern people who have got used to numerous conveniences of urban life and want to enjoy out-of-town leisure, are not ready to stay without a warm bed, shower and electricity. Therefore, a new type of leisure is for them glamping that combines nature benefits and civilization conveniences.

The advantages of this type of business are low competition, and a lack of it in some regions; quick repayment despite a considerable volume of investments; relative resistance of the project to unfavorable economic trends, and also the possibility to change a concept quickly; the prospects for expanding business due to involvement of foreign tourists. The probable risks are selection of a wrong location; equipment breakdown; an increase in the share of permanent costs; unfavorable climate; a change in the legislative base and stronger regulation in this area of activities.

The target audience of glamping is families with children who want to stay in nature territories, couples who arrange romantic trips or those who decide to organize a wedding ceremony outdoors, large groups of friends, who need to leave an urban vanity, foreign tourists, investigating Ukraine, and corporate clients who organize events out of town for their employees.

There are many women who like to spend time outdoors with comfort. As a rule, they are companies of young girls or women who prefer uniting by interests. From the point of view of marketing, they share information being active users of social networks, often post their photos, write about their impressions and give recommendations to other people.

Such a type of leisure is more practiced by family couples of older age, who have been married for several years. They think it is better to take children with them, use grounds for picnics actively, hire bicycles and boats ${ }^{17}$.

Currently there are not many glampings in Ukraine, however, each of them has its own specificity and offers unique services. Firstly, they are glampings, located in the southern regions (Odesa and Zaporizhzhia regions) near the seas or rivers. They are visited by lovers of active leisure at the seaside, as a rule, for a week. Secondly, the camps, situated in the mountain regions. Their clients can walk in the mountains under supervision of experienced guides, go snowboarding or skiing and practice in climbing. Not only glampings but also houses in the cliffs can be built there, such a variant is very popular in Canada and Mexico. Thirdly, thematic glampings, located in the places with interesting history. It concerns the territory of the Western Ukraine where tourists can see unique landmarks and enjoy picturesque sceneries. Fourthly, therapeutic glampings are an absolutely new trend that can be developed in

${ }^{17}$ Biznes-plan hlempinha [A business-plan of glamping]. URL: https://www.beboss.ru/ bplans-glamping. 
Kherson region near the famous pink lakes or warm geysers. People can come to such places to find spiritual balance, go in for yoga and meditation and take a course in restoration massage.

In terms of legislation, business is started with the state registration of an entity of entrepreneurship - a physical person-entrepreneur or a juridical person.

Running business without registration is illegal and can lead to the penalty of 17-34 thousand UAH with probable confiscation of equipment, goods and profit. If its owner breaks the law for the second time, the penalty will reach 85 thousand UAH. Moreover, running business without licenses is also punished (if they are envisaged by the law).

Entrepreneurs usually acknowledge the necessity to legalize their business sooner or later. Almost all more or less known internet-sites require documents concerning business registration, and big counteragents do demand them ant it is also necessary for participating in different tenders.

Thus, business must be registered. Nowadays it is not difficult to register business - it can be done online. In any case, the development of business without its state registration is impossible.

One can search for an investor for business or start business on their own, but a business-plan is necessary in any case. It outlines aims, presents estimates, evaluates competitors, considers weaknesses and strengths, assesses risks and predicts profitability and time of repayment.

A business-plan will help find investors and persuade them to believe in the idea. It is necessary for an entrepreneur to understand their product and its value for the market. It presents all the characteristics, details and aspects of your business, since it contains financial calculations, things necessary for launching, describes the product, its strengths and weaknesses, characterizes the target market, provides estimates, considers costs and profits, and also indicates a juridical type of the company and includes necessary documents.

To understand what you should start with (a PE (private entrepreneur) or a juridical person), it is necessary to think about:

- possible annual business turnover;

- approximate amount of costs (goods, services, equipment, buildings etc.);

- evaluation of potential counteragents;

- determination of types of activities;

- possibility of involving partners or investors;

- prediction of probable risks and tenant responsibilities.

The most popular types of running business in Ukraine are a PE and a LLC (Limited Liability Company). 
Each type of business has its advantages and disadvantages. Therefore, it is necessary to consider aspects which are more appropriate for a certain activity.

It is easier to register a PE and make its financial statements. It can be in the first, second or third group of a simplified taxation system. But in case of entrepreneurial risks a PE is liable to creditors by the property they own (in particular, accommodation, cars etc.), and answers for their activities to inspectors, law bodies and other authorities. A PE cannot employ a director and delegate these authorities to him/her. In addition, a PE cannot share authorized capital with a partner or an investor. It does not allow them to participate in business. Another disadvantage of a PE is the impossibility to sell it as an independent business.

A LLC is the most widespread type of a juridical person in Ukraine. It is possible to involve partners and investors, share authorized capital and profits, build a certain structure with the distribution of functions between different management bodies. The advantage of juridical persons is the possibility to sell them as an independent business with all its assets. The disadvantage of a LLC is a complicated procedure of closing it, more costs to register and serving it when compared to a PE.

The list of documents for registering a LLC: its name; address of registration (location); types of activities (codes of CTEA); passports and identification codes of promoters and directors; the amount of authorized capital and its distribution between promoters (if there are more than one); taxation system; the type of a foundation document (statute). All these data are referred to the solution to start a LLC, signed by its promoters. If they have not chosen a model status, that solution also confirms the statute. The signatures of the promoters must be certified by a notary.

Only a passport and an identification code are necessary to register a PE. An entrepreneur should also decide on the types of activities (codes of CTEA) and a taxation system in the future.

The activity can be started immediately after the state registration. At first an entity of entrepreneurial activity will be in a common taxation system and a single tax or a VAT can be applied, for instance, in the following month. Registration of a book for incomes and expenses can also be important for PEs. Tax authorities can do it up to two weeks. It does not correspond to such slogans as "the state is in your smartphone", but no alternative to it has been offered yet. To perform operations with non-cash payments, it is necessary to open a bank account. But it does not usually take much time ${ }^{18}$.

${ }^{18}$ Yak vidkryty svii biznes: instruktsiia z reiestratsii ta pidvodni kameni [How to start a business: the instruction on registration and pitfalls]. URL: https://thepage.ua/ua/ exclusive/yak-vidkriti-svij-biznes-instrukciya-z-reyestraciyi 
The main problem for glamping in Ukraine is a novelty of the concept for the legislation (there is no glamping in any regulatory acts) and for the Ukrainians who do not understand what they are offered. There are no such words as "glamping" and "glamp" in the legislative base of Ukraine. When receiving a certificate of compliance, glamps are classified as tents. It causes misunderstanding between entrepreneurs and inspectors. When an inspector sees that a tent has been registered, but it is a true construction, though it is light, but big enough when compared to a tent, - there is some dissonance.

Currently the project on creating the glamping "Aktove" is being realized. This project is an attempt to apply a mechanism of social entrepreneurship in the village Aktove in Mykolaiv region which has huge tourism potential since it is located near the National Park "Buzk's Gard". Actove canyon is a unique complex of forest and water ecosystems with an ensemble of cliffs and granite boulders, a natural phenomenon that has no analogues in Europe. By its geological-landscape characteristics Aktove canyon is similar to the worldfamous canyons of North America with the depth of more than $70 \mathrm{~m}$ and the area of 250 ha. The nature complex is a part of the National Nature Park "Buzk's Gard", which became one of the winners of the national contest "Seven Wonders of Ukraine" in 2010.

However, in the territories adjacent to the Park there is an acute problem of the development of rural areas. The problems of unemployment, a lack of public welfare and the development of the territory by means of investments or grants are the main ones in the villages. The location of these settlements near attractive nature objects has considerable tourism potential, but very often village communes are not capable of taking such opportunities efficiently to attract additional finances and further use them for developing villages and improving living conditions and leisure of their dwellers ${ }^{19}$.

In the west of Ukraine there are certain plans to develop a new type of leisure. For instance, in Ivano-Frankivsk region there is a project "Glampings - creation of an exclusive tourism product in nature reserves", which was submitted to the program of the sector budget support of the EU. This project implies the creation of a chain of glampings in Ivano-Frankivsk, Zakarpattia and Lviv regions. Suitable sites are selected in the national nature parks. It is one of the most high-quality and advanced projects, submitted to the sector support. It is expected that each region will receive about 5-6 million UAH within the framework of the project.

${ }^{19}$ Davydenko I.V. Hlempinh yak perspektyvna forma rozvytku ekoturyzmu [Glamping as a promising form of eco-tourism development]. URL: http://www. vestnik-econom.mgu.od.ua/journal/2017/26-1-2017/4.pdf 


\section{CONCLUSIONS}

It is necessary to understand that a new format of tourism will add a social component, expand possibilities for local entrepreneurs and also assist in creating new jobs. Such an enterprise must be unique, unusual and original and have all the characteristics of comfortable life.

The possible risks are a choice of a wrong place; equipment breakdown; an increase in the share of fixed costs; unfavorable climate; change in a legislative base and stricter regulation in this area of activity. The main problems for glamping development in Ukraine are novelty of the legislation concept (it is not included in any regulatory document) and the fact that Ukrainians are not aware of what they are offered. Ukraine' legislative base does not contain such words as "glamping" and "glamp".

\section{SUMMARY}

Modern people are accustomed to numerous conveniences of city life and want to enjoy out-of-town leisure, they are not ready to stay without a warm bed, shower and electricity, therefore there is a new type of leisure for them glamping which combines advantages of nature and modern conveniences. The benefits of this type of business are low competition and a lack of it in some regions; rapid repayment, in spite of a considerable volume of investments; relative stability of the project to unfavorable economic tendencies, and also a possibility of a fast change in the concept; prospects for expanding business due to involving foreign tourists.

The purpose of the study is to substantiate the prospects of developing hotels in the style of glamping as a new trend in hospitality industry under conditions of a market economy. The monograph presents theoretical generalization of the preconditions and approaches to the development of glamping in Ukraine at the present stage; to identify and analyze the main factors that have the most significant impact on the current state of glamping development; to determine the role of this business and its function in the development of the national economic complex of the country under conditions of market relations.

\section{REFERENCES}

1. Shcho take hlempinh ta de yoho shukaty v Ukraini [What is glamping and where it can be found in Ukraine]. URL: https://veterdoit.com/shcho-takehlempinh-ta-de-yoho-shukaty-v-ukraini/ (Accessed 20 March 2021).

2. Namet $\mathrm{z}$ kondytsionerom ta Wi-Fi: shcho take hlempinh ta chy ye vin $\mathrm{v}$ Ukraini [A tent with an air-conditioner and Wi-Wi: what is glamping and if it is available in Ukraine]. URL: https://shotam.info/namet-zkondytsionerom-ta-wi-fi-shcho-take-hempinh-ta-chy-ie-vin-v-ukraini/ (Accessed 20 March 2021). 
3. Hranovska, V. H. \& Boiko, V. O. (2020), Funktsionuvannia ekohoteliv v Ukraini yak chynnyk aktyvizatsii pidpryiemnytskoi diialnosti [Functioning of eco-hotels in Ukraine as a factor of activization of entrepreneurial activity]. Ekonomika APK, 3, pp. 57-65. [In Ukrainian] DOI: https://doi.org/ 10.32317/2221-1055.202003057

4. Glemping: v Ukraine poyavilsia novyy biznes generiruyushchiy pribyl' [Glamping: a new business has appeared in Ukraine that generates profits]. URL: http://derevo.ua/articles/details/glemping-v-ukrainepoyavilsya-novyj-biznes-generir-99 (Accessed 20 March 2021).

5. Boiko, V.O. (2020), The development of green tourism in the southern region. Entrepreneurship in the agrarian sector: global challenges and effective management: Proceedings of the $1^{\text {st }}$ International scientific practical conference in 2 parts, (pp. 65-68). 12-13 liutoho 2020, Zaporizhzhia, Ukraine : ZNU.

6. Boiko, V. O. (2020), Green tourism as a perspective direction for rural entrepreneurship development. Scientific approaches to modernizing the economic system: vector of development : collective monograph. Lviv-Toruń : Liha-Pres, 2020. pp. 1-18.

7. Boiko, V.O., and Drahota, I.P. Glamping is an exclusive tourism product of the present. The $1^{\text {st }}$ International Science Conference on Multidisciplinary Research, January 19-21, 2021, Berlin, Germany, pp. 208-210.

8. Romanenko, Y. O., Boiko, V. O., Shevchuk, S. M., Barabanova, V. V., \& Karpinska, N. V.(2020). Rural development by stimulating agro-tourism activities. International Journal of Management, № 11(4), C. 605-613. DOI: 10.34218/IJM.11.4.2020.058

9. Kyrylov, Y., Hranovska, V., Boiko, V., Kwilinski, A., \& Boiko, L. (2020). International Tourism Development in the Context of Increasing Globalization Risks: On the Example of Ukraine's Integration into the Global Tourism Industry. Journal of Risk and Financial Management, 13(12), 303. DOI: https://doi.org/10.3390/jrfm13120303

10. Boiko, V. (2020), "Rural green tourism in Ukraine: problems and prospects", Agrosvit, vol. 22, pp. 58-65. DOI: 10.32702/2306-6792. 2020.22.58

11. Boiko, V. O., Kliuchnyk, A. V., and Pivnova, L. V. (2020), "Increasing competitiveness of enterprises of ecological (green) tourism". Bulletin of Kherson National Technical University, vol. 3, pp. 213-222. DOI: https://doi.org/10.35546/kntu2078-4481.2020.3.28

12. Petruk, V.H. et al. Ekoheohrafiia ta ekoturyzm: pidruchnyk [Ecogeography and eco-tourism: textbook / V.H. Petruk, O.V. Bondarchuk, I.A. Trach, O.Yu. Panasiuk, Yu.I. Tsaruk, V.D. Vakoliuk. Vinnytsia : LLC "Nilan-LTD", 2016. 178 p. 
13. Ekoturyzm u sviti [Eco-tourism in the world]. URL: https:// we.org.ua/rizne/ekoturyzm-u-sviti/ (Accessed 22 March 2021).

14. Oliinyk, O.V., Mostetska, T.L., Tarasiuk, H.M., Chahaida, A.O. Perspektyvy rozvytku hoteliv u styli hlempinh v Ukraini [Prospects for the development of hotels in the style of glamping in Ukraine]. Ekonomika, upravlinnia ta administruvannia [Economics, management and administration], №4(90), 2019. P. 38-46.

15. Biznes-plan hlempinha [A business-plan of glamping]. URL: https://www.beboss.ru/bplans-glamping (Accessed 22 March 2021).

16. Yak vidkryty svii biznes: instruktsiia $\mathrm{z}$ reiestratsii ta pidvodni kameni [How to start a business: the instruction on registration and pitfalls]. URL: https://thepage.ua/ua/exclusive/yak-vidkriti-svij-biznes-instrukciya-zreyestraciyi (Accessed 22 March 2021).

17. Davydenko, I.V. Hlempinh yak perspektyvna forma rozvytku ekoturyzmu [Glamping as a promising form of eco-tourism development]. URL: http://www.vestnik-econom.mgu.od.ua/journal/2017/26-1-2017/4.pdf (Accessed 22 March 2021).

\section{Information about the author: Boiko Viktoriia Oleksandrivna,}

$\mathrm{PhD}$, Associate Professor,

Associate Professor at the Department of Tourism, Hotel and Restaurant Business and Foreign Languages

Kherson State Agrarian and Economic University 23, Stritenska str., Kherson, Ukraine, 73006 orcid.org/0000-0002-8032-5731 